\title{
The Effects of Acidic and Basic Pumice on Physico-Mechanical and Durability Properties of Self-Compacting Concretes
}

\author{
Hasan Erhan Yücel ${ }^{\circledR}$, Hatice Öznur Öz ${ }^{*}{ }^{\circledR}$, Muhammet Güneş ${ }^{(}$ \\ Department of Civil Engineering, Nigde Omer Halisdemir University, 51240 Nigde, Turkey \\ E-mail: oznuroz@ohu.edu.tr
}

Received: 18 August 2020; Revised: 09 September 2020; Accepted: 10 September 2020

\begin{abstract}
In this study, properties of self-compacting concretes (SCCs) containing acidic and basic pumice (AP-BP) was investigated. SCCs incorporating AP-BP (SCCAs-SCCBs) were produced with constant slump flow diameter of $720 \pm 20 \mathrm{~mm}$ and $690 \pm 20 \mathrm{~mm}$ by adjusting superplasticizer (SP), respectively. Control mixture was designed with totally crushed stone aggregate. SCCAs and SCCBs could be produced up to $100 \%$ coarse AP with $20 \%$ increments and $60 \%$ coarse BP with $10 \%$ increments, respectively, to ensure the desired limit values for SCC. Firstly, fresh properties of SCCs were determined. Then, the mechanical and durability properties of SCCs were measured at 28 and 56 days. Test results indicated that workability properties of SCCAs are markedly higher than that of SCCBs. Additionally, mechanical and durability performances of SCCs decreased with increasing of AP and BP. The compressive strengths of SCCs containing $60 \% \mathrm{AP}$ and BP decreased approximately $28-29 \%$ and $22-24 \%$, compared to the control mixture, respectively. Similarly, modulus of elasticity of same mixtures decreased around $35-39 \%$ and $17-19 \%$, respectively. However, all results indicated that SCCs produced with AP and BP provided the available limits in the design of SCC. Additionally, SCCBs exhibited higher performance than SCCAs in terms of hardened properties. Moreover, high correlation coefficients $\left(\mathrm{R}^{2}>0.89\right)$ between the durability and mechanical properties were found for SCCs.
\end{abstract}

Keywords: self-compacting concrete, acidic pumice, basic pumice, physico-mechanical and durability properties, correlation

\section{Introduction}

Self-compacting concrete (SCC) is an innovative and indispensable concrete type which capable of filling up the formwork, providing better compaction, passing-ability in restricted and confined areas without segregation or bleeding by self-weight thanks to its high workability. Therefore, SCC provides reduction in the labor cost because of no need vibration and gaining time [1-3].

Water/binder (w/b) ratio and the quantity of coarse aggregate used in the SCC are lower than those of conventional concrete. Therefore, in order to avoid the addition of a large quantity of cement, SCCs contain alternative cementitious minerals such as silica fume, metakaolin, fly ash (FA), blast furnace slag, lime powder, natural pozzolan and nanoparticles. These minerals can prevent separation of the larger particles in the fresh mixture and gain additional strength by pozzolanic reaction in the hardened state [4-7]. However, the workability, the main design parameter of SCC, can be improved by the incorporation of FA with spherical shape [8]. Due to storage problems of FA, it causes

Copyright (C2020 Hatice Öznur Öz, et al.

DOI: https://doi.org/10.37256/gbce.112020591

This is an open-access article distributed under a CC BY license

(Creative Commons Attribution 4.0 International License)

https://creativecommons.org/licenses/by/4.0/ 
great damage to the environment by pollution of air and water. Turkey has 11 thermal power plants and these plants burn annually 50 million tons of lignite coal. Approximately 12 million tons/year of FA obtained from coal are left in the natural environment as waste [9]. Less than $1 \%$ of the FA from thermal power plants in Turkey can be used in building applications. By 2020, 50 million tonnes of waste ash is expected to occur annually in thermal power plants [9, 10]. However, despite of the storage issues of FA, it has been utilized in the limited area of construction industry. The use of FA in the production of concrete is extremely important due to environmental effect as well as the sustainable concrete development [11].

SCCs cause more lateral loads to the structures and increase the dead load of the structures during the earthquake. Therefore, utilization of lightweight aggregates (LWAs) in the production of concrete provides significant benefits such as reducing dead loads and formwork pressure, increasing the resistance to earthquake thanks to the reduction of the self-weight of the structures [11,12]. Moreover, not only the problem of segregation of LWAs can prevent but also the workability property of SCC can be improved by LWA [13]. The natural LWAs can be exemplified as pumice, diatomite, perlite, vermiculite, pozzolan, tuff, volcanic cinder, scoria, bottom ash and oil palm shell. Moreover, artificial lightweight aggregates such as clay, expanded clay, slag, slate and shale are produced via special process [11, 14]. In recent years, there has been focused on usage of pumice aggregates (PAs) as the most popular natural lightweight aggregate in the producing of lightweight concretes in Turkey [15]. Pumice is a material of volcanic origin and occurs naturally. Moreover, pumice occurs as a result of the disentanglement of gases in the course of the formation of lava. While total pumice reserve of the world is around 18 billion $\mathrm{m}^{3}$, total pumice reserve of Turkey is around 7.4 billion $\mathrm{m}^{3}$ [16]. Specific structure of pumice has been consisted by air voids or bubbles when gases in molten lava are trapped during cooling [17]. Therefore, pumice ensures significant advantages such as high sound and heat insulation property and low weight by the way of continuous and discontinuous porous structure [18, 19]. In addition, pumice is characterized a high porosity and a low elasticity modulus [20]. Two types of pumices are formed as a result of volcanic activities; acidic pumice (AP) and basic pumice (BP). Basic pumice can also be termed as basaltic pumice or scoria [21]. Acidic pumice with white and off-white color has a hardness of 5-6 according to Mohs scale and a density of $0.5-1 \mathrm{~g} /$ $\mathrm{cm}^{3}$. The BP has a hardness of 5-6 and a density of $1-2 \mathrm{~g} / \mathrm{cm}^{3}$ and it can be dark and brownish blackish colored $[21,22]$. Additionally, AP has lower rough surface with respect to BP [23, 24].

When the previous studies are examined, Değirmenci and Yilmaz [25] reported $75 \%$ and $60.7 \%$ decrease at 28 days for compressive and flexural strengths of mortar including 100\% pumice in the dimensions of 0-4 mm compared to the control mixture, respectively. Karakoç et al. [26] showed that compressive strength, ultrasonic pulse velocity and relative dynamic modulus of elasticity of high strength concretes were reduced with the increasing ratios of PA (in 0-2 $\mathrm{mm}$ grain size). Moreover, for the same study [26], at the end of 300 freezing and thawing cycles, porosity was increased up to $12 \%$ for high strength concrete incorporating PA. Gökçe et al. [27] stated that lightweight reactive powder concrete can be developed with including pumice as fine aggregate (size 0-1 $\mathrm{mm}$ ) with the compressive strength of 69 and $176 \mathrm{MPa}$. Kabay et al. [28] determined lower mechanical performance of concretes incorporating 50\% and $100 \%$ pumice (size 1-4 mm). Hossain et al. [18] observed $28 \%, 27 \%$ and $30 \%$ reduction at 28 days for compressive strength, modulus of elasticity and tensile strength with including pumice (size 0.15-4.75 mm), respectively. However, Kaffetzakis and Papanicolaou [29] reported that SCC with pumice considerably increased bond strength. Minapu et al. [30] indicated that the compressive, tensile and flexural strengths of concretes designed with $10 \%-50 \%$ pumice decreased 5\%-22\%, 9\%-35\% and 10\%-53\%, respectively. Similarly, Kashyap and Sasikala [31] determined that the compressive strength of concretes incorporating pumice in the range of $10 \%$ and $40 \%$ reduced between $9 \%-21 \%$ at 28 days. Hossain et al. [18] determined that mechanical performance of the concrete decreased and drying shrinkage of the concrete increased with increase in coarse lightweight volcanic PA ratio used instead of coarse gravel aggregate. Pravallika and Rao [32] observed reduction in the range of 7\%-47\% and $1 \%-48 \%$ at 7 and 28 days for compressive of concretes containing 10\%-50\% pumice. Splitting tensile strength decreased by $9 \%-35 \%$ and $5 \%-33 \%$ at 7 and 28 days, respectively. The reduction in the 7 and 28 days flexural strength was $3 \%-31 \%$ and $0.61 \%-30.36 \%$, respectively. Additionally, Sancak et al. [33], Parhizkar et al. [34], Değirmenci and Yilmaz [25] and Kurt et al. [35, 36] observed higher water absorption of concrete incorporating pumice compared to control concrete.

Considering the effect of pumice aggregate on characteristics of self-compacting lightweight concrete (SCLC), Gönen and Yazıcıoğlu [37] showed that SCLC incorporating perlite had lower compressive strength than that of SCLC designed with BP at 28 days. On the other hand, compressive strengths per unit weight of SCLCs are higher than those 
of SCCs without LWA. Kadiroğlu [38] indicated that compressive, splitting tensile and flexural strength values of SCC along with crushed stone aggregate is higher than that of SCLC incorporating PA in the ratios of approximately $68 \%$, $16 \%$ and $30 \%$, respectively. Also, it was determined that, the water absorption rates of SCLCs are considerably higher than those of normal weight concrete. Additionally, Topçu and Uygunoğlu [39] reported that SCLC with LWAs (PA, volcanic tuff and diatomite) having lower unit weight has lower physical and mechanical properties. In addition to these properties, apparent porosity and water absorption values of SCC increased with increase in LWAs.

As evidenced by previous studies, there are some studies on the PA usage as LWA in the SCC. These studies are usually focused on the workability or mechanical performances of SCLC incorporating AP. In addition, the comparative effect of AP and BP on the workability, mechanical and durability properties of SCC has not been investigated. This study has been presented the test results obtained from the effects of two types of PA on the workability, mechanical and durability performances of SCC. Moreover, the manufacture of lightweight concrete is in most countries an extremely mechanized industry depending on excellent accuracy and automation. This manufacture has to match strict standards that describe properties determined for the products. These may include denotations on strength, sizes, insulating properties, weather resistance and fire resistance. PA can be utilized as lightweight aggregates in concrete that meets all these requirements [15].

In the view of literature reviews, it was investigated the physico-mechanical performances of SCC designed with coarse AP and BP. Therefore, at first, the main design parameters such as the w/b and replacement ratio of AP and $\mathrm{BP}$ with crushed stone aggregate were determined to obtain the desired workability limitations of SCC. After that, control mixture (SCC-C) was produced with crushed stone aggregate without AP and BP. Self-compacting concrete incorporating AP (SCCA) and self-compacting concrete incorporating $\mathrm{BP}$ (SCCB) were produced by using AP in the ratios of $20 \%, 40 \%, 60 \%, 80 \%$ and $100 \%$ and $\mathrm{BP}$ in the ratios of $20 \%, 30 \%, 40 \%, 50 \%$ and $60 \%$ instead of the crushed stone, respectively. Therefore, a total of 11 SCC mixes were produced by using LWAs. Finally, compressive, splitting tensile and flexural strengths, modulus of elasticity, water sorptivity, water permeability and rapid chloride permeability tests were applied at 28 and 56 days, respectively.

\section{Material and methods}

\subsection{Cement, FA and SP}

Ordinary Portland cement (CEM I 42.5R similar to ASTM I type cement) and Class F FA as a second binder material was used in all SCCs. 20\% Class F FA was added to the all mixtures instead of cement. Physical properties and chemical compositions of cement and FA used in the design of SCCs are listed in Table 1. Superplasticizer (SP) was utilized to reach the desired workability. Specific gravity of polycarboxylic ether type SP is 1.07.

Table 1. Physical properties and chemical compositions of cement and FA

\begin{tabular}{ccc}
\hline Chemical Analysis (\%) & Cement & FA \\
\hline $\mathrm{CaO}$ & 62.58 & 2.24 \\
$\mathrm{SiO}_{2}$ & 20.25 & 57.2 \\
$\mathrm{Al}_{2} \mathrm{O}_{3}$ & 5.31 & 24.4 \\
$\mathrm{Fe}_{2} \mathrm{O}_{3}$ & 4.04 & 7.1 \\
$\mathrm{MgO}$ & 2.82 & 2.4 \\
$\mathrm{SO}_{3}$ & 2.73 & 0.29 \\
$\mathrm{~K}_{2} \mathrm{O}$ & 0.92 & 3.37 \\
$\mathrm{Na}_{2} \mathrm{O}$ & 0.22 & 0.38 \\
Loss of Ignition & 2.96 & 1.52 \\
Specific Gravity & 3.15 & 2.04 \\
Blaine Fineness $\left(\mathrm{m}^{2} / \mathrm{kg}\right)$ & 326 & 379 \\
\hline
\end{tabular}




\subsection{Aggregates}

In this study, while crushed sand and natural sand were utilized as fine aggregate, crushed stone and pumice were used as coarse aggregate. The natural sand from river was utilized to increase the workability of SCC because of natural process of attrition tends to possess better smoother surface texture and shape. It also carries moisture that is trapped in between the particles. Crushed sand with angular, rough surface structure and low grain size $(0-2 \mathrm{~mm})$ was used to meet the strength and durability requirement of SCC. AP and BP aggregates were used instead of crushed stone aggregate separably 4-8 $\mathrm{mm}$ and 8-16 mm grain sizes. Specific gravity values of crushed sand, natural sand, crushed stone, (48) AP, (8-16) AP, (4-8) BP and (8-16) BP aggregates were determined as 2.67, 2.63, 2.65, 1.15, 0.99, 2.17 and 2.09, respectively. Additionally, Figure 1 shows views of AP and BP, and Figure 2 presents SEM analysis results of AP and BP. Figure 2 indicated that AP has lower rough surface and higher porous structure than that of BP. According to ASTM C127 [40] water absorption capacity of AP in the 4-8 $\mathrm{mm}$ and $8-16 \mathrm{~mm}$ grain size was determined as $47.6 \%$ and $33.2 \%$ respectively. However, water absorption capacity of BP in the 4-8 $\mathrm{mm}$ and $8-16 \mathrm{~mm}$ grain size was measured as $9.42 \%$ and $8.15 \%$, respectively. The high water absorption capacity of the AP can be explained with its high void ratio shown in Figure 2.

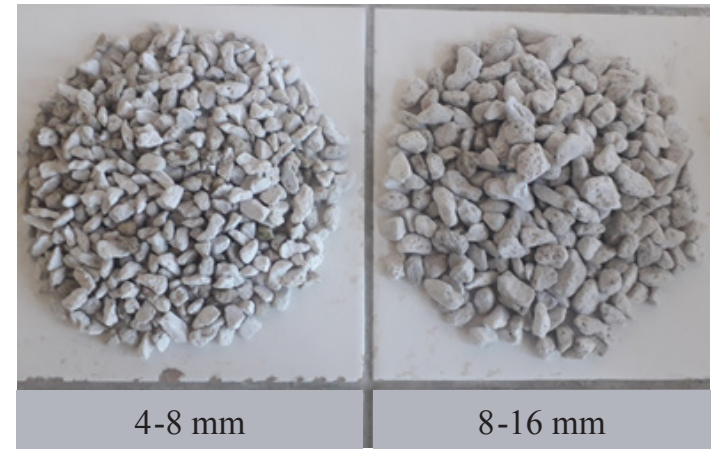

(a)

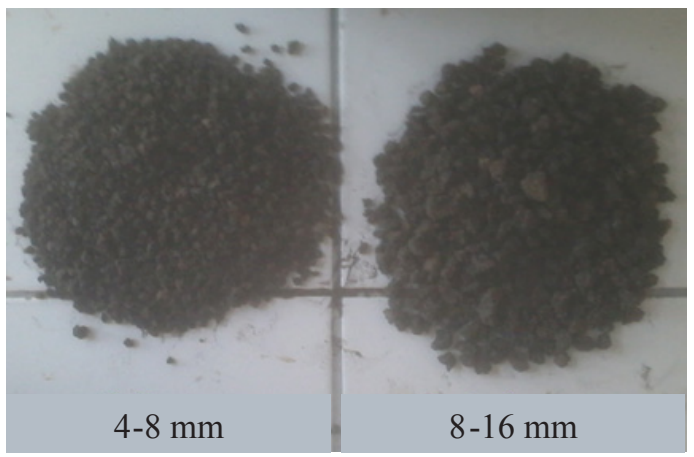

(b)

Figure 1. Images of (a) AP view, (b) BP view

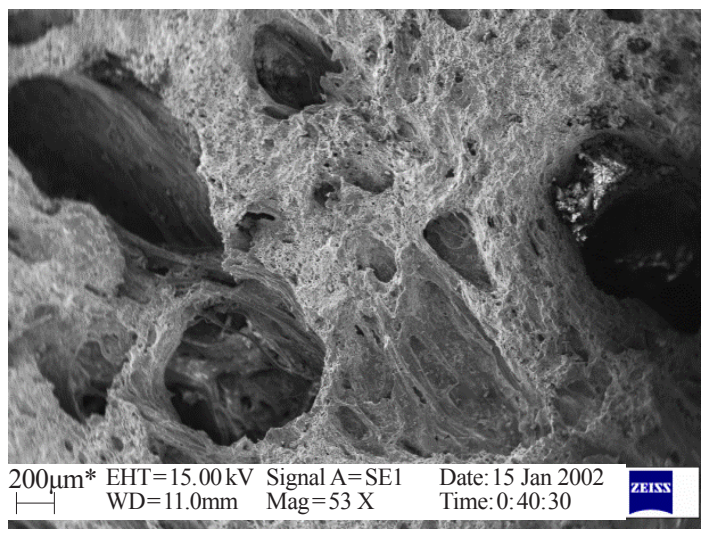

(a)

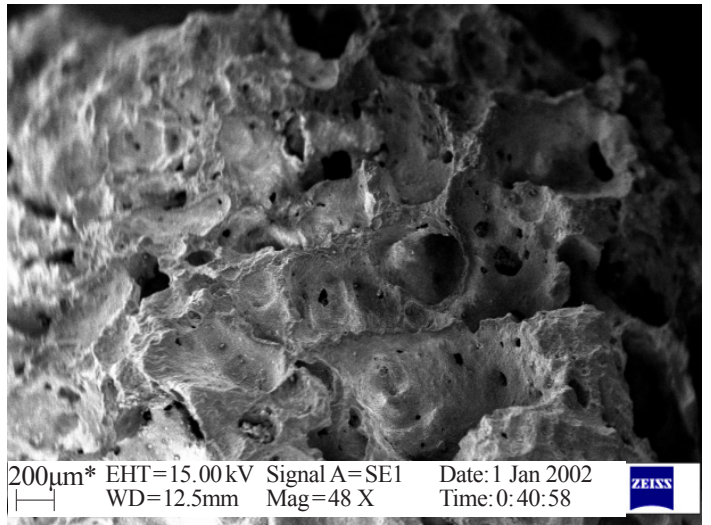

(b)

Figure 2. SEM view of (a) AP, (b) BP

\subsection{Concrete mixture proportioning, casting}

The batching and mixing procedure of SCCs was performed with respect to ASTM C192 / C192M [41] Mixture ratios of SCCs is given in Table 2. A total of 11 SCC mixes were produced to investigate the effects of AP and BP on 
the mechanical and durability properties of SCC. SCCs were produced along with total binder content $(80 \%$ cement and $20 \% \mathrm{FA}$ ) of $550 \mathrm{~kg} / \mathrm{m}^{3}$ and constant water/binder ratio (0.32). The process of replacement in the SCCA was conducted in volume fractions from $20 \%$ to $100 \%$ at $20 \%$ increments. And then, the process of replacement in the SCCB was conducted in volume fractions from $20 \%$ to $60 \%$ at $10 \%$ increments in order to obtain EFNARC limitations for the desired workability [42]. Before mixing, because of the high water absorption of AP and BP (particularly AP), they were submerged in water throughout 24 hours to ensure adequate saturation and then by wiping with the aid of the towel before the mixing to make the pumice saturated surface dry condition. Control mixture of SCC (SCC-C) was prepared with $100 \%$ crushed aggregates. In this study, the mixture codes were identified in accordance with the content and type of pumice in mixture composition. For example, SCCA20 and SCCB20 are self-compacting concrete incorporating $20 \%$ AP and self-compacting concrete incorporating $20 \%$ BP, respectively.

Table 2. Mixture ratios of SCCs $\left(\mathrm{kg} / \mathrm{m}^{3}\right)$

\begin{tabular}{|c|c|c|c|c|c|c|c|c|}
\hline \multirow{3}{*}{ Code } & \multirow{3}{*}{ Water/Binder } & \multirow{3}{*}{ Binder } & \multicolumn{3}{|c|}{ Coarse Aggregate } & \multicolumn{2}{|c|}{ Fine Aggregate } & \multirow{3}{*}{ SP } \\
\hline & & & \multirow{2}{*}{$\begin{array}{c}\text { Crushed Stone } \\
\text { 4-16 mm }\end{array}$} & \multicolumn{2}{|c|}{ Pumice } & \multirow{2}{*}{$\begin{array}{c}\text { Crushed Sand } \\
0-2 \mathrm{~mm}\end{array}$} & \multirow{2}{*}{$\begin{array}{c}\text { Natural Sand } \\
0-4 \mathrm{~mm}\end{array}$} & \\
\hline & & & & $4-8 \mathrm{~mm}$ & $8-16 \mathrm{~mm}$ & & & \\
\hline SCC-C & 0.32 & 550 & 822 & 0 & 0 & 244.7 & 579.8 & 7.50 \\
\hline SCCA20 & 0.32 & 550 & 657.6 & 35.7 & 30.70 & 244.7 & 579.8 & 6.61 \\
\hline SSCA40 & 0.32 & 550 & 493.2 & 71.3 & 61.4 & 244.7 & 579.8 & 5.00 \\
\hline SCCA60 & 0.32 & 550 & 328.8 & 107 & 92.1 & 244.7 & 579.8 & 4.64 \\
\hline SCCA80 & 0.32 & 550 & 164.4 & 142.7 & 112.8 & 244.7 & 579.8 & 4.14 \\
\hline SSCA100 & 0.32 & 550 & 0 & 178.4 & 153.5 & 244.7 & 579.8 & 3.93 \\
\hline SCCB20 & 0.32 & 550 & 657.6 & 67.3 & 64.8 & 244.7 & 579.8 & 6.96 \\
\hline SCCB30 & 0.32 & 550 & 575.4 & 101 & 97.2 & 244.7 & 579.8 & 6.43 \\
\hline SCCB40 & 0.32 & 550 & 493.2 & 134.6 & 129.7 & 244.7 & 579.8 & 6.07 \\
\hline SCCB50 & 0.32 & 550 & 411 & 168.3 & 162.1 & 244.7 & 579.8 & 5.71 \\
\hline SCCB60 & 0.32 & 550 & 328.8 & 201.9 & 194.5 & 244.7 & 579.8 & 5.36 \\
\hline
\end{tabular}

\subsection{Mechanical tests}

Compressive strengths of SCCs were identified using cubic samples in dimensions of $150 \mathrm{~mm}$ with respect to ASTM C39 [43]. Splitting tensile strength was determined using cylindrical specimens in dimensions of $100 \times 200 \mathrm{~mm}^{3}$ according to ASTM C496 [44]. Beam specimens in dimensions of $100 \times 100 \times 400 \mathrm{~mm}^{3}$ were utilized to measure flexural strength values of SCCs according to ASTM C293 / C293M-10 [45]. Static modulus of elasticity test was measured with respect to ASTM C469 [46]. The samples were loaded three times up to 40\% of the final compressive load identified on the compressive test. Readings for each cube were calculated by taking the average of the results obtained from the samples at each testing age. These four basic mechanical properties were identified by calculating the average of the values measured from 3 specimens.

\subsection{Durability tests}

Water sorptivity coefficient was determined on $\varnothing 100 \times 50 \mathrm{~mm}^{3}$ cylinder specimens cut from $\varnothing 100 \times 200 \mathrm{~mm}^{3}$ cylinders. Before the tests, the samples were dried at $100 \pm 5^{\circ} \mathrm{C}$ through an oven till they achieved the fixed mass. During the test, the concrete surface was left in contact with water. The test was applied to SCC mixtures at 28 and 56 days, respectively.

TS EN 12390-8 [47] was implemented to determine the water penetration depth of SCCs at 28 and 56 days. For this reason, the bottom side of the specimen was subject to a $500 \pm 50 \mathrm{kPa}$ water pressure for $72 \mathrm{hrs}$. The cube specimens were cut into the middle section and the maximum water penetration depth was determined as mm. According to TS 
EN 12390-8 [47], the maximum water penetration depth of concrete should not exceed $50 \mathrm{~mm}$ so that it is said to be resistant to chemical attack of concrete. If the concrete will be exposed to aggressive condition, the maximum water penetration depth of concrete should not exceed $30 \mathrm{~mm}$ with respect to TS EN 12390-8 [47].

An experimental setup with respect to the ASTM C1202 [48] was followed to measure the impedance of SCCs against chloride ion permeability. Chloride ion permeability was determined on $\varnothing 100 \times 50 \mathrm{~mm}$ cylinder specimens cut from $\varnothing 100 \times 200 \mathrm{~mm}$ cylinders. To prevent evaporation of water from the saturated sample, the vacuum-saturation procedure was applied through 2 hours and then, paraffin was implemented onto the lateral surface of the samples. The samples were located in a test cell. The current passing through the specimens was measured over a 6 hours period. 5 classes from 'Negligible' to 'High' were categorized according to ASTM C1202 [48] depending on total coulomb value.

\section{Results and discussions}

\subsection{Fresh properties}

SCCAs and SCCBs were designed to acquire a slump flow diameter of $720 \pm 20 \mathrm{~mm}$ and $690 \pm 20 \mathrm{~mm}$ by adjusting the quantity of SP, respectively [42]. AP was improved the workability of SCCs by decreasing of T500 slump time and V-funnel flow time as well as increasing of slump flow and L-box height-ratio [24]. The main reason for the increase workability of AP is low unit weight. Additionally, the SP ratio was reduced as the BP rate increased to provide the same slump flow range in all SCC mixes. However, BP could be used up to $60 \%$ to provide the EFNARC limit values [42]. Therefore, for same mixture ratios, SCCBs has lower workability than the SCCAs. Moreover, SCCs incorporating BP lead to increase T500 time and V-funnel flow time and to decrease slump flow and L-box height-ratio with decreasing SP [23]. Fresh concrete properties provided the EFNARC limitations [42]. The fresh properties of SCCs incorporating $\mathrm{AP}$ and BP are given in Table 3. Designed concretes were produced in accordance with the SF2 class $(660-750 \mathrm{~mm}$ slump flow diameter) specified in EFNARC [42].

Table 3. Experimental results of fresh concrete

\begin{tabular}{ccccc}
\hline Code Number & $\begin{array}{c}\mathrm{T}_{500} \text { time } \\
\mathrm{s}\end{array}$ & $\begin{array}{c}\text { Slump flow diameter } \\
\mathrm{mm}\end{array}$ & $\begin{array}{c}\text { V-funnel flow time } \\
\mathrm{s}\end{array}$ & $\begin{array}{c}\text { L-box height-ratio } \\
\mathrm{h}_{2} / \mathrm{h}_{1}\end{array}$ \\
\hline SCC-C & 3.53 & 700 & 17.02 & 0.85 \\
SCCA20 & 3.51 & 710 & 15.70 & 0.87 \\
SSCA40 & 3.31 & 720 & 14.49 & 0.88 \\
SCCA60 & 2.87 & 720 & 11.47 & 0.91 \\
SCCA80 & 2.67 & 730 & 10.24 & 0.94 \\
SSCA100 & 2.29 & 730 & 08.53 & 0.96 \\
SCCB20 & 3.54 & 700 & 18.25 & 0.84 \\
SCCB30 & 3.67 & 695 & 19.42 & 0.84 \\
SCCB40 & 3.86 & 680 & 20.04 & 0.83 \\
SCCB50 & 4.01 & 670 & 21.17 & 0.82 \\
SCCB60 & 4.21 & 670 & 23.00 & 0.80 \\
\hline
\end{tabular}

\subsection{Compressive strength and modulus of elasticity}

Compressive strength and modulus of elasticity results of SCCs are presented graphically in Figure 3 and Figure 4, respectively. Maximum compressive strength of SCC mixtures was obtained from control concrete (SCC-C) for both ages. However, compressive strength was reduced as the replacement ratio of pumice was increased. The attenuation ratio for compressive strength was obtained as $9.6 \%, 19.2 \%, 28.4 \%, 40.2 \%$ and $54.3 \%$ for SCCA20, SCCA 40 , SCCA60, SCCA80, SCCA100 compared to control mixture at 28 days, respectively. Additionally, these mixtures had 
a decrease in the ranges of $9.9 \% 19.2 \%, 28.7 \%, 38.9 \%$ and $50.5 \%$ compared to SCC-C for the compressive strength at 56 days, respectively. Adding BP to mixes, similarly, reduced compressive strength of mixtures. The compressive strength values of the SCCB 60 mixture decreased to $22.9 \%$ and $23.5 \%$ at 28 and 56 days, respectively. However, for the same replacement ratios, the compressive strengths of SCCAs were lower than those of SCCBs. For example, while the compressive strength values of the SCCA20 was found as $60 \mathrm{MPa}$ and $67.4 \mathrm{MPa}$, the compressive strength values of the SCCB20 mixture was $63.6 \mathrm{MPa}$ and $70.4 \mathrm{MPa}$ at 28 and 56 days, respectively.

The modulus of elasticity of concrete varies depending on the type of aggregates, the volume of the cement, the hydrated cement matrix and the water/binder ratio $[39,49]$. Therefore, the modulus of elasticity of SCC varied with increased amount of AP and BP. For example, modulus of elasticity for SCC-C, SCCA60 and SCCB60 mixtures were determined as $35.1 \mathrm{GPa}, 21.4 \mathrm{GPa}$ and $28.4 \mathrm{GPa}$ at 28 days, and $37.7 \mathrm{GPa}, 24.7 \mathrm{GPa}$ and $31.1 \mathrm{GPa}$ at 56 days, respectively. According to these results, modulus of elasticity values of the SCCAs is lower than that of SCCBs.

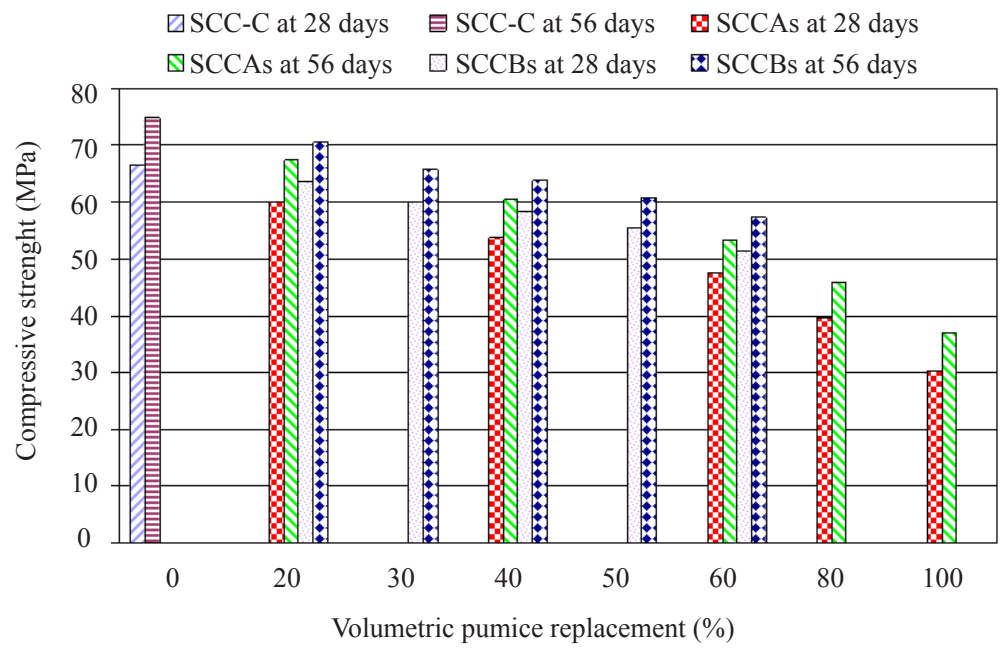

Figure 3. Compressive strength of SCCs at 28 and 56 days

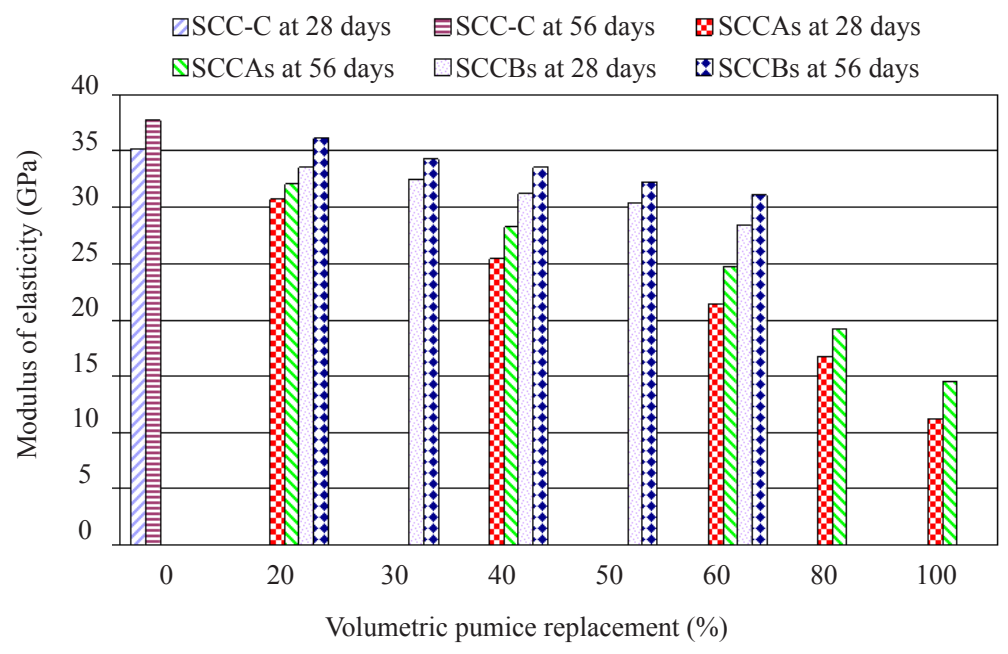

Figure 4. Modulus of elasticity of SCCs at 28 and 56 days

According to the compressive strength and modulus of elasticity test results, the mechanical performance of the SCCs decreased with increased amount of AP and BP. Similarly, Rao et al. [50] determined 30\%, 52\%, 56\%, 68\% and $76 \%$ decrease at 28 days for compressive strength of concretes containing $20 \%, 40 \%, 60 \%, 80 \%$ and $100 \%$ pumice 
as coarse aggregate substitution, respectively. Desai et al. [51] and Sivalingarao et al. [52] reported aproximately 17$13 \%, 46-30 \%, 61-57 \%$ and $69-61 \%$ decrease at 28 days for compressive strength of concretes incorporating $25 \%$, $50 \%, 75 \%$ and $100 \%$ pumice as coarse aggregate substitution, respectively. Literature studies $[16,53-55]$ indicated that compressive strength of concretes reduced with including pumice. Other studies $[18,55,57]$ demonstrated that the modulus of elasticity of concrete decreased with including of pumice. Reductions in the compressive strength and modulus of elasticity values at 28 and 56 days might be due to the weak structure (porous structure ranged from completely open to completely closed) of PAs [16, 18, 26, 39]. Moreover, an explanation for lower compressive strength and modulus of elasticity of the SCCs incorporating PAs may be determined in the microstructure variation of the SCC. The capillary pores in the SCC will be changed on a large scale by null pores that are the residuals of the saturated PA (particularly AP) [26]. However, the test results indicated that SCCs incorporating BP were obtained better results in terms of these two tests with respect to SCCs incorporating AP. It is known that compressive strength changes depending on the density [26]. For example, many researches [18, 26, 37, 38] indicated that compressive strength decreased due to the density reduced with increasing the usage ratio of LWA in place of the normal aggregate. Therefore, this situation can be connected to fact that BP has higher density with respect to AP.

\subsection{Splitting tensile strength}

Splitting tensile strength values of SCCs are plotted in Figure 5. Minimum splitting tensile strengths of SCCs was given from SCCA100 mixture at 28 and 56 days. As a result of comparisons between SCC-C and SCCA100, it was observed a reduction in the proportions of $38.7 \%$ and $31.4 \%$ at 28 and 56 days, respectively. However, the range of splitting tensile strength varied from 4.05 $\mathrm{MPa}$ to $5.08 \mathrm{MPa}$ at 28 days and from $4.5 \mathrm{MPa}$ to $5.5 \mathrm{MPa}$ at 56 days, depending on increased BP ratio. Similarly, Rajeswari and Sunilaa [54] observed that splitting tensile strength of concretes incorporating 50\%,60\% and 70\% pumice reduced. In other study, Rao et al. [50] indicated that splitting tensile strength of concretes designed with $20 \%, 40 \%, 60 \%, 80 \%$ and $100 \%$ pumice decreased $22 \%, 39 \%, 56 \%, 58 \%$ and 65\%, respectively. Gesoğlu et al. [58] demonstrated that splitting tensile strength of SCCs decreased with increased LWAs due to the strength limitations of LWAs. It can be also clearly seen that for the same mixture ratios, the effect on splitting tensile strengths of SCCs incorporating BP is higher than those of SCCAs. The effect of strength performances of cement paste increases depending on increasing aggregate density. In addition to strength performances of concrete containing LWA or varying aggregate types, other performance properties of concrete can be also determined by the aggregate properties [39]. The study prepared by Andiç-Çakır and Hızal [59] indicated that the splitting tensile strengths of concretes are depended on the aggregate density used in the mixture. Additionally, failure of SCCAs can be attributed to the poor interfacial zone between cement paste and AP. The main reason for this is the high void ratio of the AP. At the same time, it is estimated that there are stronger bonds between cement matrix and BP for SCCBs. This can be explained with the fact that BP contains much less void than AP [39].

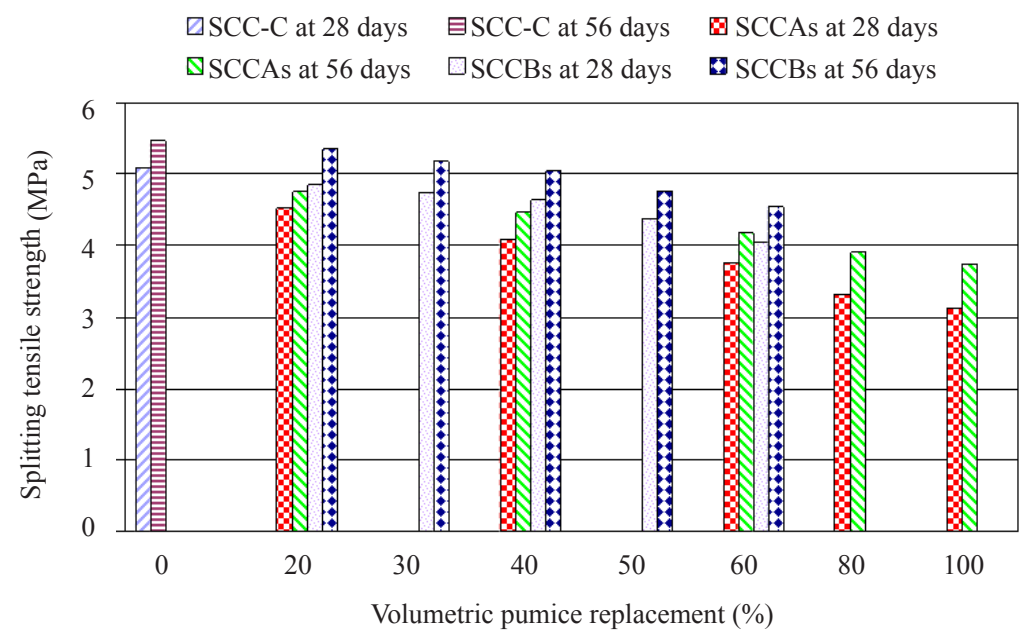

Figure 5. Splitting tensile strength of SCCs at 28 and 56 days 


\subsection{Flexural strength}

The graphical presentation of flexural strength data of SCCs were presented in Figure 6. The flexural strength of SCC-C is 1.1, 1.2, 1.3, 1.4, 1.5 (for 28 days) and 1.1, 1.2, 1.3, 1.4, 1.4 (for 56 days) times higher than those of the SCCs incorporating $20 \%, 40 \%, 60 \%, 80 \%$ and $100 \%$ of AP, respectively. Therefore, flexural strength of SCCs reduced with including AP. Hariyadi and Tamai [55] reported that the 28 days flexural strength of concretes incorporating 50\% and $100 \%$ pumice coarse aggregate reduced up to $13 \%$ and $33 \%$, respectively. In other study, Kiliç et al. [60] determined around 58\% decrease in the 28 days flexural strength of concretes incorporating fine and coarse pumice aggregates compared to the control. Additionally, when LWAs such as AP was used in place of any material having high density such as crushed stone, weaker bonds occured between AP and cement paste [61]. Similarly to the results of SCCAs, comparative results of SCCB60 and SCC-C indicated that there was a decrease of $19.3 \%$ and $19.2 \%$ at 28 and 56 days, respectively. When same replacement ratios were considered, flexural strength of SCCA60 were determined as $5.1 \mathrm{MPa}$ and $5.78 \mathrm{MPa}$ for 28 and 56 days, however, flexural strength of SCCB60 is higher 7.3\% and 1.7\% than these values, respectively. It can be explained that interlocking between PA and cement matrix is better for BP than AP due to the surface of BP is more roughly than that of AP as seen in Figure 2 [39].

\subsection{Water sorptivity and water permeability}

Figure 7 and Figure 8 present the variation in the sorptivity coefficient and water penetration depth of SCCs at 28 and 56 days, respectively. The test data demonstrated that sorptivity coefficient increased with the increase of pumice amount. Sorptivity coefficients were measured as $0.0775 \mathrm{~mm} / \mathrm{min}^{0.5}$ and $0.0584 \mathrm{~mm} / \mathrm{min}^{0.5}$ for SCC-C, $0.1205 \mathrm{~mm} /$ $\mathrm{min}^{0.5}$ and $0.1008 \mathrm{~mm} / \mathrm{min}^{0.5}$ for SCCA60 and $0.0957 \mathrm{~mm} / \mathrm{min}^{0.5}$ and $0.078 \mathrm{~mm} / \mathrm{min}^{0.5}$ for SCCB60 at 28 and 56 days, respectively. According to these results, sorptivity coefficient of SCCAs was higher than that of SCCBs.

Water permeability test measures the depth of water penetration into concrete as a result of differential pressure. According to test results, water penetration depth increased depending on the increase of pumice amount used in the SCCAs and SCCBs. Similarly, Hossain et al. [18] noted the decrease ratios of 5.4\%, $10.81 \%$ and $18.92 \%$ in the 12 weeks water permeability of concretes incorporating 50\%,75\% and 100\% pumice aggregate as coarse aggregate substitution. Water penetration depth of SCC-C was found as $19.2 \mathrm{~mm}$ and $15.2 \mathrm{~mm}$, however, SCCA60 had a water penetration depth of $38.4 \mathrm{~mm}$ and $30.1 \mathrm{~mm}$ in comparison with SCCB60 having a water penetration depth of $28.6 \mathrm{~mm}$ and $22.1 \mathrm{~mm}$ at 28 and 56 days, respectively. As seen in Figure 7, while all SCCs are resistant to chemical attack due to having water penetration depth of less than $50 \mathrm{~mm}$, however, SCC-C, SCCBs and SCCA20, SCCA40 (for only 56 days) were resistant to aggressive media at 28 and 56 days [47].

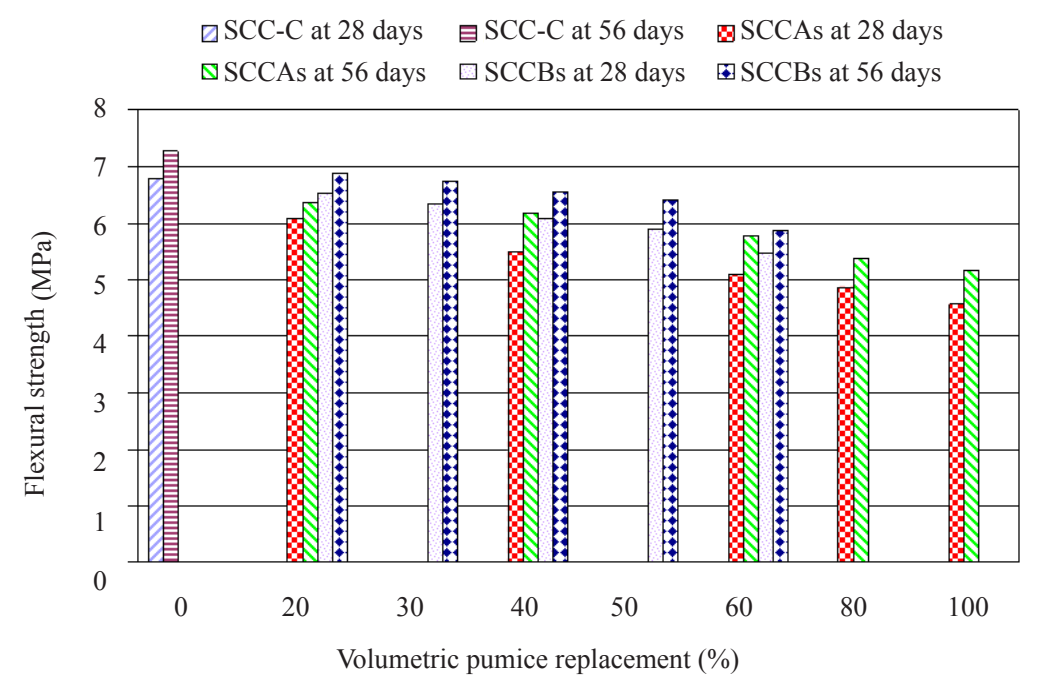

Figure 6. Flexural strength of SCCs at 28 and 56 days 
The porous structure of the aggregates plays a major role on durability of concrete $[26,39,62]$. This situation is supported by SEM analysis of AP and BP shown in Figure 2. In this figure, it can be seen that, AP has higher porous structure and lower rough surface than those of BP. Therefore, durability properties of SCCBs are better than those of SCCAs. Moreover, it can be expressed the water absorption capacity of AP and BP was higher than that of crushed stone aggregate as well as the porous structure [37]. Test results indicated that adherence of SCC with AP due to its high porous structure and low rough surface was fairly weak in comparison to SCC incorporating BP.

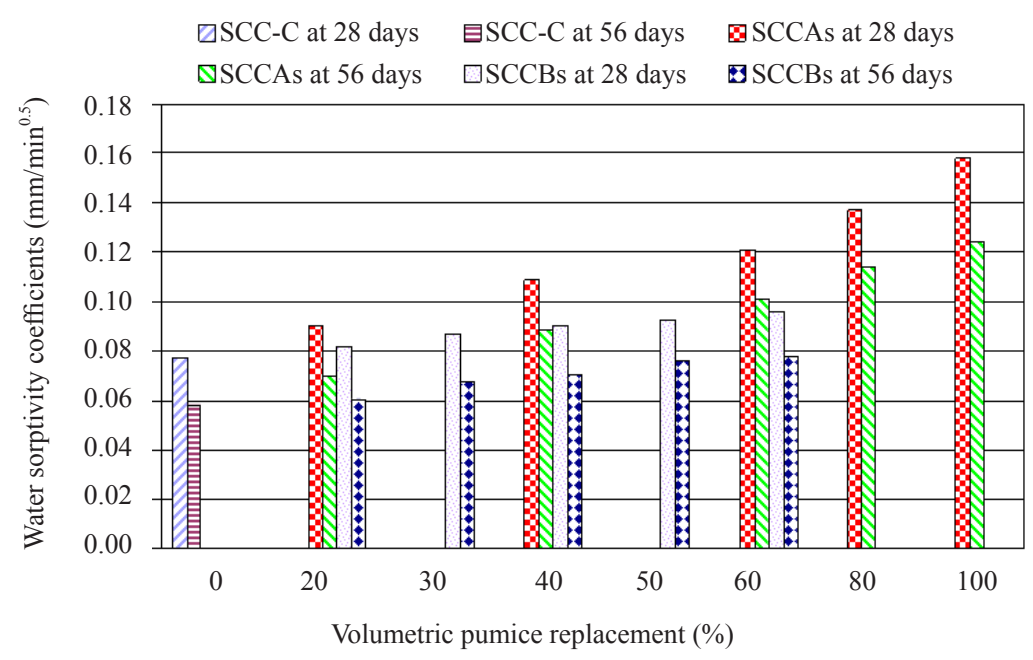

Figure 7. Water sorptivity coefficients of SCCs at 28 and 56 days

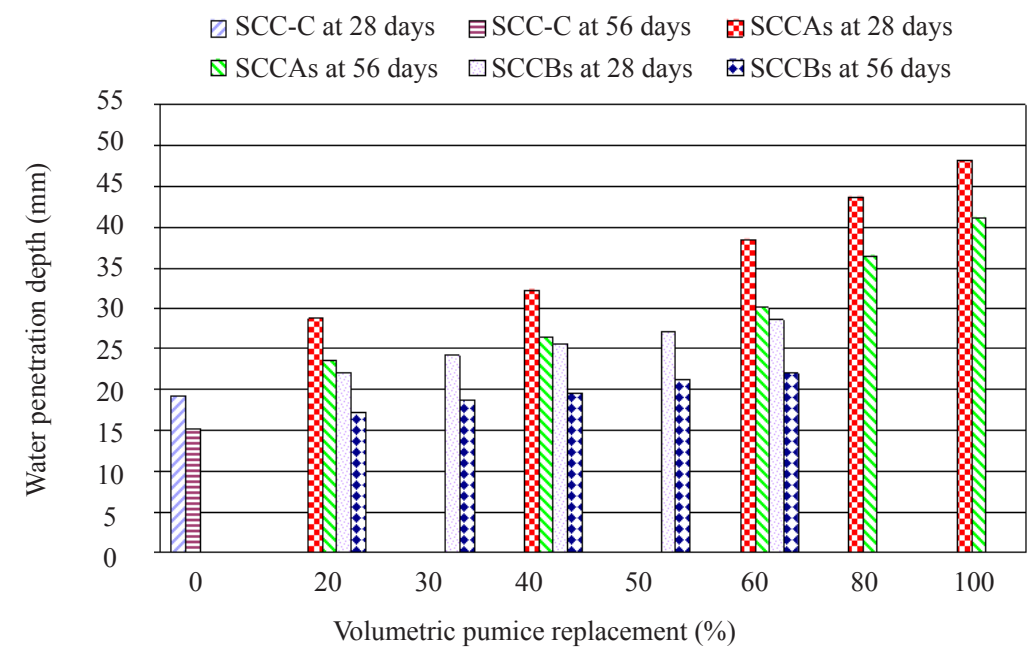

Figure 8. Water penetration depth of SCCs at 28 and 56 days

\subsection{Rapid chloride permeability}

The resistance chloride ion penetration of concrete is expressed as the total charged passed in Coulombs-C. According to chloride ion penetrability expressed in ASTM C1202 [48], the total charge passed through SCCAs and SCCBs was presented graphically in Figure 9. As shown in Figure 9, chloride-ion permeability increased along with the increment of AP and BP at 28 and 56 days. Considering the experimental study at 28 days, the total charge passed through for SCCs were determined in the range of 2000-3500 C for SCCAs and 2000-3000 C for SCCBs. Therefore, according to ASTM C1202 [48], all SCCs have moderate chlorine ion permeability for 28 days. However, because of 
reduction void ratio of the samples with longer curing times, the 56 days values of SCC mixtures provided low chloride ion permeability in terms of ASTM C1202 [48]. The poor performance in terms of chloride ion permeability can be depend upon the poor and weak quality due to porous micro and macro structures of AP and BP aggregates. Compared with SCCAs and SCCBs, chloride ion permeability of SCCBs was closer to SCC-C due to porous structure of BP is lower than that of AP. According to rapid chlorine permeability test results, all SCCs can be considered as a preventive element for structures having chlorine attack risk. In addition, it is known that rapid chloride permeability test less dependent on the ionic composition of pore solution and more on its porosity and pore tortuosity [63]. It is considered that the presence in the pore system of AP and BP aggregates, have been affected negatively the formality of the pore network tortuosity of SCC with their rough and hollow structure.

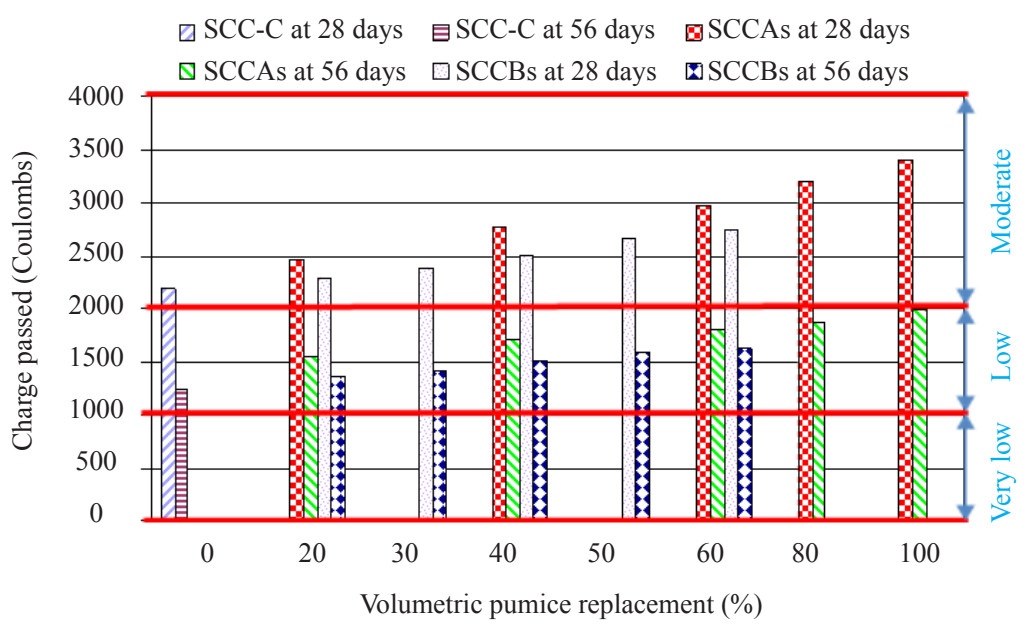

Figure 9. Charge passed (Coulombs) of SCCs at 28 and 56 days

\subsection{Relationships between the properties of SCCs}

Correlation (relationship) of test results is one of the leading methods among the researchers for evaluation of the reported experimental data. Theoretically, the main factor governing the mechanical and durability properties of concrete / SCC are the pore structure of the matrix, the relative volume fractions of matrix and aggregate, and the quality of interfacial transition zone. Occasionally researchers present the relation between different transport properties to underline and significantly state the strength and durability properties of the concretes [55, 64-68]. In the current paper, relationships between modulus of elasticity, flexural strength, splitting tensile strength, charge passed, water penetration depth, water sorptivity coefficient with the compressive strength were presented Figure 10 for 28 and 56 days. According to analysis results, high correlations values between durability and other mechanical properties with compressive strength of SCCs were found. As seen in Figure 10, since $\mathrm{R}^{2}>0.90$, all the correlation relations were determined as the linear fit. In addition, order to determine the relationship between the mechanical properties of SCCs, elasticity modulus-flexural strength, elasticity modulus-splitting tensile strength and flexural strength-splitting tensile strength graphs were given in Figure 11 for 28 and 56 days. In these three graphs, the correlation coefficient was found to be higher than 0.89 at 28 and 56 days. The relationships between the durability properties mentioned in the study were also examined and the results were shown in Figure 11. Correlation coefficients indicated that the durability characteristics of SCCs were highly relationship (>0.91) with each other.

\section{Conclusions}

In this study, the effects of AP and BP on mechanical and durability performances of SCCs were investigated. According to these tests data, the following statement can be drawn; 
The workability of SCCs was improved by using PA. However, BP could be used up to $60 \%$ of replacement ratio in order to obtain the desired workability limitations ratio for SCC.

The compressive strength, modulus of elasticity, splitting-tensile strength and flexural strength of SCC containing $100 \%$ AP compared to the control mixture reduced in the ranges of 50-55\%, 61-67\%, 31-38\% and 28-33\%, respectively. The same properties of SCC containing $60 \%$ BP in comparison with the control mixture decreased in the ranges of $22-$ $24 \%, 17-19 \%, 16-20 \%$ and $19-20 \%$, respectively. PA and the cement matrix was quite low due to the weak character of the pumice. Additionally, considering same mixture proportions, it was demonstrated that reduction in the mechanical performances of SCCBs is lower than those of SCCAs. This situation, it can be attributed that density of BP is higher than that of AP.

Durability properties of SCCs deteriorated with increment amount of pumice used in the mixture. However, these values of SCCAs are higher than those of SCCBs because of the high porous structure and low rough surface of AP supported by SEM analysis.

Finally, high relationships between durability properties and other mechanical properties with compressive strength of SCCs were determined. In addition, the mechanical performances and durability performances of SCCs were correlated with each other. The fact that the lowest correlation coefficient was more than 0.89 showed that the findings of the study were quite meaningful.

The role of AP and BP in SCC could be explored more comprehensively by performing scanning electron microscopy (SEM) and mercury industry porosimetry (MIP) analyses on SCCs. Thus, this study could be enriched in microstructural terms. This situation can be considered as the shortage of current research.
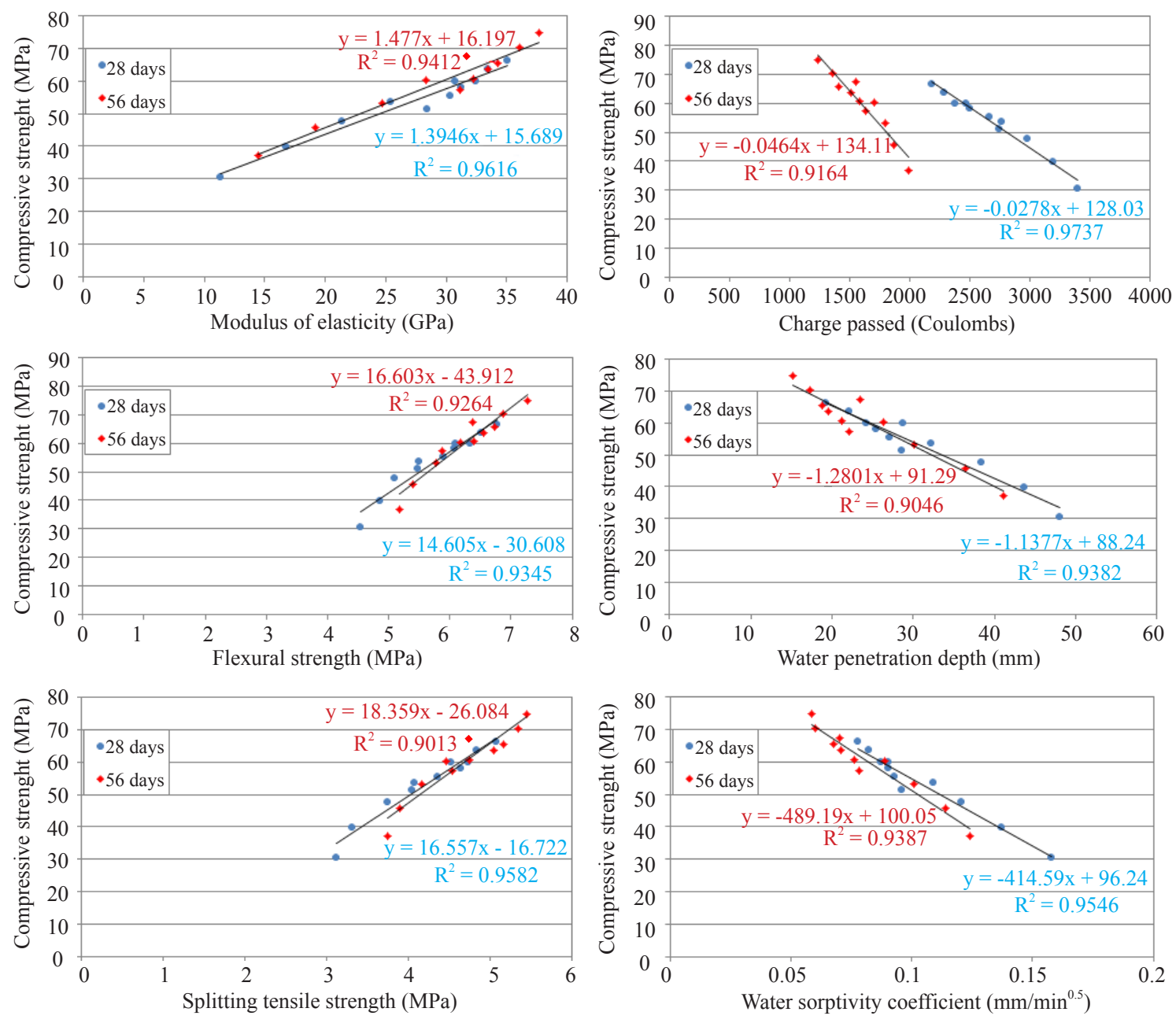

Figure 10. Correlation relations between durability and other mechanical properties with compressive strength 

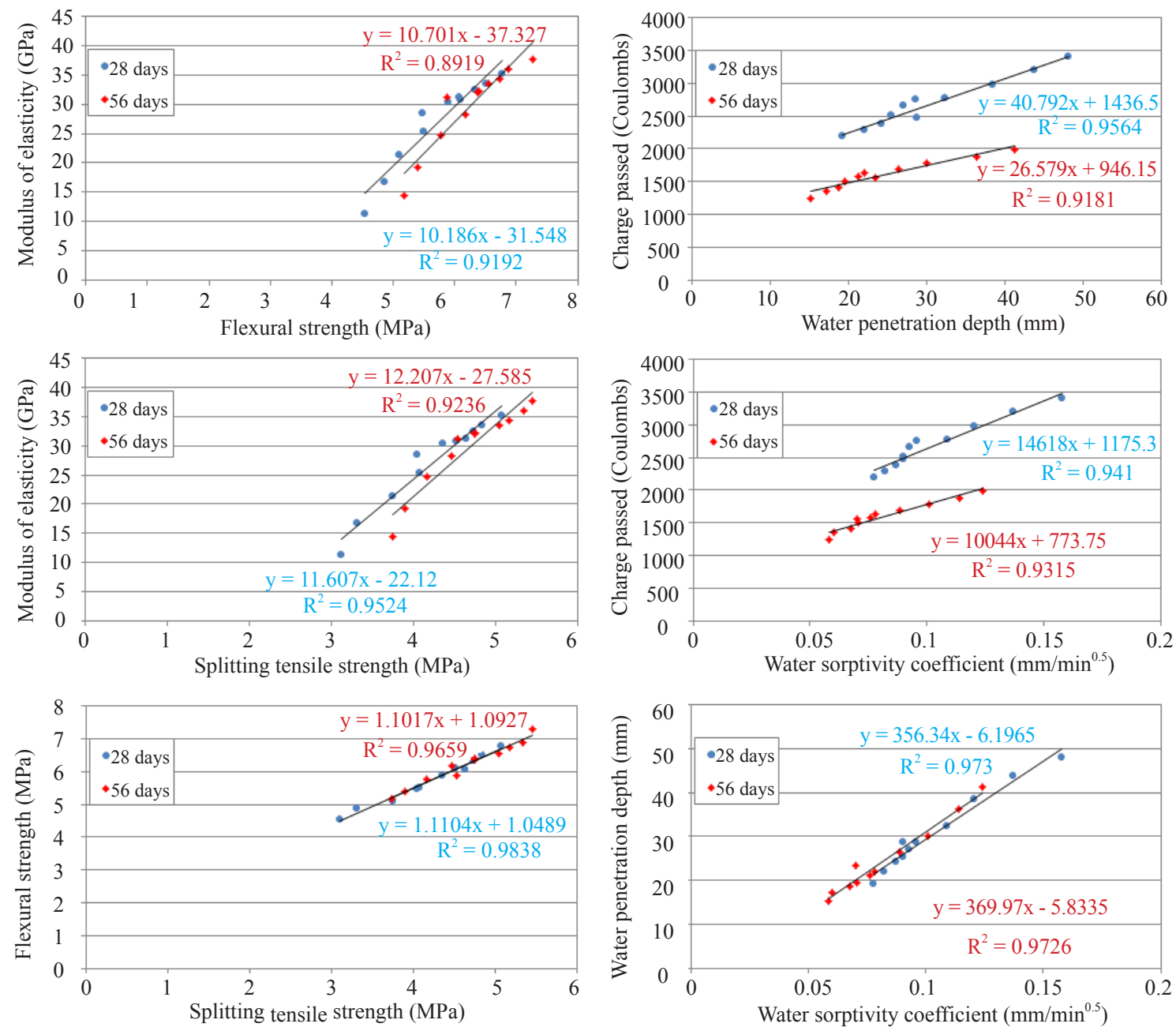

Figure 11. Correlation relations between mechanical properties, and correlation relations between durability properties

\section{Conflict of interests}

There is no conflict of interests associated with this publication and there is no financial fund for this work that can affect the research outcomes.

\section{References}

[1] Ngo H-T, Kadri E-H, Kaci A, Ngo T-T, Trudel A, Lecrux S. Advanced online water content measurement for selfcompacting concrete production in ready-mixed concrete plants. Constr Build Mater. 2016; 112: 570-580.

[2] Teixeira S, Santilli A, Puente I. Analysis of casting rate for the validation of models developed to predict the maximum lateral pressure exerted by self-compacting concrete on the vertical formwork. J Build Eng. 2016; 6: 215-224.

[3] Wasim M, Hussain RR. Passive film formation and corrosion initiation in lightweight concrete structures as compared to self-compacting and ordinary concrete structures at elevated temperature in chloride rich marine environment. Constr Build Mater. 2015; 78: 144-152.

[4] Dogan UA, Ozkul MH. The effect of cement type on long term transport properties of self-compacting concretes. Constr Build Mater. 2015; 96: 641-647.

[5] Granata MF. Pumice powder as filler of self-compacting concrete. Constr Build Mater. 2015; 96: 581-590.

[6] Khalaj G, Nazari A. Modeling split tensile strength of high strength self compacting concrete incorporating randomly oriented steel fibers and $\mathrm{SiO}_{2}$ nanoparticles. Constr Build Mater. 2008; 22: 1394-1401. 
[7] Khatib JM. Performance of self-compacting concrete containing fly ash. Constr Build Mater. 2008; 22: 1963-1971.

[8] Silva P, de Brito J. Electrical resistivity and capillarity of self-compacting concrete with incorporation of fly ash and limestone filler. Adv Concr Constr. 2013; 1(1): 65-84.

[9] Demir İ. Uçucu külün hafif yapı malzemesi üretiminde kullanılması. Yapı Tek Elek Derg. 2005; 1: 21-24.

[10] Tütünlü F, Atalay Ü. Utilization of fly ash in manufacturing of building bricks. International Ash Utilization Symposium USA. Lexington, USA: University of Kentucky; 2001. p.13.

[11] Öz HÖ. Properties of self-compacting concretes made with cold bonded fly ash lightweight aggregates [dissertation]. Gaziantep(Turkey); 2014.

[12] Gönen T, Yazıcıoğlu S. Pomza agregalı kendiliğinden yerleşen hafif betonların donma-çözülme direnci. Ulusal Beton Kongresi Antalya. Turkey; 2015. p.192-201.

[13] Felekoğlu B. Kendiliğinden yerleşen betonun fiziksel ve mekanik özelliklerinin araştırılması. Yüksek Lisans Tezi Dokuz Eylül University, Institute of Science, İzmir, Turkey; 2003. p.267.

[14] Mo KH, Alengaram UJ, Jumaat MZ, Liu MYJ, Lim J. Assessing some durability properties of sustainable lightweight oil palm shell concrete incorporating slag and manufactured sand. J Clean Product. 2016; 112: 763770 .

[15] Gündüz L. The effects of pumice aggregate / cement ratios on the low-strength concrete properties. Constr Build Mater. 2008; 22: 721-728.

[16] Kurt M, Gül MS, Gül R, Aydin AC, Kotan T. The effect of pumice powder on the self-compactability of pumice aggregate lightweight concrete. Constr Build Mater. 2016; 3: 36-46.

[17] Ulusu H, Aruntas HY, Gencel O. Investigation on characteristics of blended cements containing pumice. Constr Build Mater. 2016; 118: 11-19.

[18] Hossain KMA, Ahmed S, Lachemi M. Lightweight concrete incorporating pumice based blended cement and aggregate: Mechanical and durability characteristics. Constr Build Mater. 2011; 25: 1186-1195.

[19] Celik S, Family R, Menguc MP. Analysis of perlite and pumice based building insulation materials. J. Build. Eng. 2016; 6: 105-111.

[20] Wang X, Wu Y, Shen X, Wang H, Liu S, Yan C. An experimental study of a freeze-thaw damage model of natural pumice concrete. Powder Tech. 2018; 339: 651-658.

[21] Bideci A, Gültekin AH, Yildirim H, Oymael S., Bideci Ö.S. Internal structure examination of lightweight concrete produced with polymer-coated pumice aggregate. Compos Part B. 2013; 54: 439-447.

[22] Özkan ŞG, Tuncer G. Pomza madenciliğine genel bir bakış. Journal Of Engineering Sciences. 2001; 7(2): $269-276$.

[23] Öz HÖ, Yücel HE, Güneş M. Bazik pomzanın kendiliğinden yerleşen betonların işlenebilirlik özellikleri üzerine etkisi. Omer Halisdemir University J Eng Sci. 2017; 6(1): 90-97.

[24] Yücel HE, Öz HÖ, Kömür S, Güneş M. Asidik pomza ile üretilen kendiliğinden yerleşen betonların taze özellikleri. Omer Halisdemir University J Eng Sci. 2017; 6(1): 83-89.

[25] Degirmenci N, Arin Y. Use of pumice fine aggregate as an alternative to standard sand in production of lightweight cement mortar. Indian J Eng Mater Sci. 2011; 18: 61-68.

[26] Karakoç MB, Demirboğa R, Türkmen İ, Can İ. Modeling with ANN and effect of pumice aggregate and air entrainment on the freeze-thaw durabilities of HSC. Constr Build Mater. 2011; 25: 4241-4249.

[27] Gökçe H, Sürmelioğlu Setenay S, Andiç-Çakir Ö. A new approach for production of reactive powder concrete: lightweight reactive powder concrete (LRPC). Mater Struct. 2017; 50(1): 1-9.

[28] Kabay N, B. Kizilkanat A, Tüfekçi M. Effect of prewetted Pumice aggregate addition on concrete properties under different curing conditions. Period Polytech Civ Eng. 2016; 60(1): 89-95.

[29] Kaffetzakis MI, Papanicolaou CG. Bond behavior of reinforcement in lightweight aggregate self-compacting concrete. Constr Build Mater. 2016; 113: 641-652.

[30] Minapu L, Ratnam MKMV, Rangarahu U. Experimental study on light weight aggregate concrete with pumice stone, silica fume and fly ash as a partial replacement of coarse aggregate. International J Innov Res Sci Eng Tech. 2014; 3(12): 18130-18138.

[31] Kashyap AMN, Sasikala G. An experimental study on compressive strength of steel fibre reinforced light weight aggregate (pumice stone) concrete. Int J Eng Res Dev. 2014; 9(12): 21-25.

[32] Pravallika BD, Rao KV. The study on strength properties of light weight concrete using light weight aggregate. Int J Sci Res. 2016; 5(6): 1735-1739.

[33] Sancak E, Sari D, Simsek O. Effects of elevated temperature on compressive strength and weight loss of the lightweight concrete with silica füme and superplasticizer. Cem Concr Compos. 2008; 30: 715-721.

[34] Parhizkar T, Najimi M, Pourkhorshidi AR. Application of pumice aggregate in structural lightweight concrete. 
Asian J Civ Eng. (Building and Housing). 2012; 13(1): 43-54.

[35] Kurt M, Aydin AC, Gül MS, Gül R, Kotan T. The effect of fly ash to self-compactability of pumice Aggregate lightweight concrete. Indian Academy of Sci Sad. 2015; 40(4): 1343-1359.

[36] Kurt M, Kotan T, Gül MS, Gül R, Aydin AC. The effect of blast furnace slag on the self-compactability of pumice aggregate lightweight concrete. Indian Academy of Sci Sad. 2016; 41(2): 253-264.

[37] Gönen T, Yazıcıŏlu S. Kendiliğinden yerleşen hafif betonun mekanik özelliklerine kür ortamı ve agrega tipinin etkisi. J Fac Eng Arch Gazi University. 2010; 25(3): 459-467.

[38] Kadiroğlu İ. Kendiliğinden yerleşen normal dayanımlı hafif beton üzerine deneysel bir çalışma. Batıçim Batı Anadolu Çimento Sanayii A.Ş. İzmir; 2006. p.40-48.

[39] Topçu İB, Uygunoğlu T. Effect of aggregate type on properties of hardened self-consolidating lightweight concrete (SCLC). Constr Build Mater. 2010; 24: 1286-1295.

[40] ASTM C127. Standard test method for specific gravity and absorption of coarse aggregate. Annual Book of ASTM Standards. West Conshohocken, PA, USA: ASTM International; 2007.

[41] ASTM C192/C192M. Standard practice for making and curing concrete test specimens in the laboratory. Annual Book of ASTM Standards. West Conshohocken, PA, USA: ASTM International; 2007.

[42] EFNARC. European guidelines for self-compacting concrete, specification and production and use. Association House. UK; 2005. p.1-68.

[43] ASTM C39. Standard test method for compressive strength of cylindrical concrete specimens. Annual Book of ASTM Standards. West Conshohocken, PA, USA: ASTM International; 2012.

[44] ASTM C496. Standard test method for splitting tensile strength of cylindrical concrete specimens. Annual Book of ASTM Standards. West Conshohocken, PA, USA: ASTM International; 2011.

[45] ASTM C293/C293M-10. Standard test method for flexural strength of concrete. Annual Book of ASTM Standards. West Conshohocken, PA, USA: ASTM International; 2010.

[46] ASTM C469. Standard test method for static modulus of elasticity and poisson's ratio of concrete in compression. Annual Book of ASTM Standards. West Conshohocken, PA, USA: ASTM International; 2010.

[47] TS EN 12390-8. Testing Hardened Concrete-Part 8: Depth of penetration of water under pressure. Turkish Standard Institution. Ankara, Turkey; 2002.

[48] ASTM C1202. Standard test method for electrical indication of concrete's ability to resist chloride ion penetration. Annual Book of ASTM Standards. West Conshohocken, PA, USA: ASTM International; 2012.

[49] Chandra S, Berntsson L. Lightweight aggregate concrete: science, technology and applications. New York, USA: William Andrew Publishing; 2002.

[50] Rao NS, Kumari YRR, Desai VB, Swami BLP. Fibre reinforced light weight aggregate (natural pumice stone) concrete. Int J Sci Eng Res. 2013; 4(5): 158-161.

[51] Desai VB, Arjunappa KM, Sathyam A. An experimental investigation on mode-II fracture of light weight pumice aggregate concrete. Int J Modern Eng Res. (IJMER). 2014; 4(12): 25-37.

[52] Sivalingarao N, Desai VB, Swami BLP, Mohanlal C. Strength properties of fibrous light weight concrete with pumice aggregates and steel fibre. Fibours Light Weight Concrete. 2016; 52-58.

[53] Peter R, Kumar AA. Experimental investigation of floating concrete structure using light weight (natural pumice stone) aggregate. World J Eng Res Tech. (WJERT). 2016; 2: 118-129.

[54] Rajeswari S, Sunilaa G. Experimental study of light weight concrete by partial replacement of coarse aggregate using pumice aggregate. Int J Sci Eng Res. 2015; 50-53.

[55] Hariyadi, Tamai H. Enhancing the performance of porous concrete by utilizing the pumice aggregate. Pro Eng. 2015; 125: 732-738.

[56] Dolgun, O. Kendiliğinden yerleşen betonlarda öğütülmüş pomza kullanabilirliğinin araştırılması. Nigde University, Institute of Science; 2010. p.101.

[57] Gündüz L, Uğur İ. The effects of different fine and coarse pumice aggregate / cement ratios on the structural concrete properties without using any admixtures. Cem Concr Res. 2005; 35: 1859-1864.

[58] Gesoglu M, Guneyisi E, Ozturan T, Öz HÖ, Asaad DS. Permeation characteristics of self compacting concrete made with partially substitution of natural aggregates with rounded lightweight aggregate. Constr Build Mater. 2014; 59: 1-9.

[59] Andic-Cakir O, Hizal S. Influence of elevated temperatures on the mechanical properties and microstructure of self consolidating lightweight aggregate concrete. Constr Build Mater. 2012; 34: 575-583.

[60] Kiliç A, Atiș CD, Teymen A, Karahan O, Ari K. The effects of scoria and pumice aggregates on the strengths and unit weight of lightweight concrete. Sci Res Essays. 2009; 4(10): 961-915. 
[61] Gesoğlu M, Guneyisi E, Khoshnaw G, İpek S. Abrasion and freezing-thawing resistance of pervious concretes containing waste rubbers. Constr Build Mater. 2014; 73: 19-24.

[62] Lotfy A, Hossain KMA, Lachemi M. Durability properties of lightweight self-consolidating concrete developed with three types of aggregates. Constr Build Mater. 2016; 106: 43-54.

[63] Shi C. Effect of mixing proportions of concrete on its electrical conductivity and the rapid chloride permeability test (ASTM C1202 or ASSHTO T277) results. Cem Concr Res. 2004; 34: 537-545.

[64] Gesoğlu M, Güneyisi E, Özturan M, Mermerdas K. Permeability properties of concretes with high reactivity metakaolin and calcined impure kaolin. Mater Struct. 2017; 47(4): 709-728. Avaiable from: http://dx.doi.org/10.1617/ s11527-013-0090-9.

[65] Boel V, Audenaert K, De Schutter G. Gas permeability and capillary porosity of self-compacting concrete. Mater Struct. 2008; 41: 1283-1290.

[66] Medina M, Frías MI, de-Rojas S, Thomas C, Polanco JA. Gas permeability in concrete containing recycled ceramic sanitary ware aggregate. Constr Build Mater. 2012; 37: 597-605.

[67] Hui-Sheng S, Bi-Wan X, Xiao-Chen Z. Influence of mineral admixtures on compressive strength, gas permeability, and carbonation of high performance concrete. Constr Build Mater. 2009; 23: 1980-1985.

[68] Menadi B, Kenai S, Khatib J, Ait-Mokhtar A. Strength and durability of concrete incorporating crushed limestone sand. Constr Build Mater. 2009; 23: 625-633. 